\title{
Dietary Changes across the Neolithic Levels of the Tepecik-Çiftlik Population
}

\author{
Tepecik-Çiftlik Topluluğunun Neolitik Dönem Tabakaları Boyunca \\ Beslenme Değişimleri \\ Kameray ÖZDEMIR* \\ Ali Akın AKYOL \\ Ali Metin BÜYÜKKARAKAYA***
}

\begin{abstract}
As an important mineral source for the entire organism, bone serves as a useful bioarchive for monitoring past human lifeways like diet, since the concentration of the elements in its structure is influenced by the individual diet. Human and animal bones from three different Neolithic Levels (Level 5, 4, and 3) dated to 6800 and 6100 cal. BC according to the C14 found in Tepecik-Çiftlik, Central Anatolia, were elementally (Ca, P, Mg, Mn, Sr, $\mathrm{Zn}, \mathrm{Cu}$, and $\mathrm{Pb}$ ) investigated by the help of X-ray fluorescence (XRF) spectrometry. The element content of bones refers to post-mortem alteration (diagenesis), especially for manganese and lead. Bivariate treatment of the element with calcium (element/calcium ratio) seems to demonstrate some differences between adult and subadult, male and female, and among levels. Multivariate analysis (PCA and DA) suggests a shift from meat consumption and rich subsistence economy in the lower levels to more vegetable (cereal) consumption and poor economy in the upper level. The results obtained from multivariate treatments are in agreement with the findings of archaeologists and anthropologists who conducted the excavations.
\end{abstract}

Keywords: trace elements, heavy metals, Neolithic populations, paleodiet, ancient bone, central Anatolia

$\ddot{O} \mathbf{z}$

Organizma için önemli bir mineral kaynağı olan kemiğin yapısında yer alan elementlerin derişimi beslenmeden etkilenebildiğinden, kemik diyet gibi geçmiş insan yaşam biçimlerini izlemek için yararlı bir biyolojik arşiv görevi görür. Orta Anadolu Bölgesinde yer alan Tepecik-Çiftliğin C14 tarihlemesine göre yaklaşık 6800-6100 yılları arasına tarihlenen üç farklı Neolitik Tabakasından (Seviye 5, 4 ve 3) elde edilen insan ve hayvan kemiklerinin element $(\mathrm{Ca}, \mathrm{P}, \mathrm{Mg}, \mathrm{Mn}, \mathrm{Sr}, \mathrm{Zn}, \mathrm{Cu}$ ve $\mathrm{Pb}$ ) içeriği X-1şını fluoresans (XRF) spektrometrisi yardımıyla incelenmiştir. Kemiklerin element içeriği mangan ve kurşun başta olmak üzere gömü sonrası değişime işaret etmektedir. Elementlerin kalsiyum ile (element/kalsiyum oranı) bivaret analizi yetişkin ile yetişkin yaş altı, kadın ile erkek bireyler ve tabakalar arasında farklılıklar olduğunu göstermiştir. Çok değişkenli analizler (PCA ve DA) alt katmanlarda et tüketiminden ve zengin geçinim ekonomisinden üst tabakada daha fazla bitki (örneğin tahıl) tüketimine ve fakir geçinim ekonomisine geçiş olduğunu göstermektedir. Çok değişkenli incelemelerden elde edilen sonuçlar, kazıları gerçekleştiren arkeologların ve antropologların bulguları ile uyumludur.

Anahtar Kelimeler: eser element, ağır metal, Neolitik topluluklar, peleodiyet, eski kemik, Orta Anadolu

\section{Introduction}

The stylistic and compositional investigation of the artifacts such as pottery, stone tools, metal objects, etc., along with architectural elements from an excavation site may help researchers to understand the social, economical, and cultural dynamics of the population who lived there (e.g. Uzun, 2016). The researchers from the field of biological anthropology also contribute to these attempts by analyzing skeletal remains from the same sites, if recovered.

The macroscopic, microscopic, and X-ray examination of human remains, in particular bones and teeth reveal information on demography, pathology, burial customs, bio-distance, occupational activities, migration, and, above all, dietary habits. Any changes in nutritional habits actually reflect changes in subsistence strategies, leaving traces on bones and teeth such

\footnotetext{
* Assist. Prof. Dr., Hacettepe University, Faculty of Arts, Dept. of Anthropology, kameray.ozdemir@hacettepe.edu.tr

** Assist. Prof. Dr., Gazi University, Faculty of Fine Arts, Dept. of Conservation and Restoration of Cultural Heritage, aliakyol@gazi.edu.tr

*** Assist. Prof. Dr., Hacettepe University, Faculty of Arts, Dept. of Anthropology, alimetin@hacettepe.edu.tr
}

Özdemir, K, Akyol, A , Büyükkarakaya, A . (2017). Dietary Changes across the Neolithic Levels of the TepecikÇiftlik Population. Gaziantep University Journal of Social Sciences, 16 (3), 594-610. DOI: 10.21547/jss.312067 Submission Date: 12-05-2017 Acceptance Date: 24-08-2017 
as musculoskeletal markers and tooth decay, as exemplified by the transformation from hunting-gathering to sedentary life (Corti et al., 2013).

The composition studies of bone elements and stable isotopes utilizing advanced techniques can supply more direct traces to the reconstruction of paleodiet at the molecular level. The elements found in the composition of the bone such as strontium (Sr), zinc ( $\mathrm{Zn})$, magnesium $(\mathrm{Mg})$, lead $(\mathrm{Pb})$, and barium $(\mathrm{Ba})$ have a direct relationship with diet (Klepinger, 1984; Lambert et al., 1979). They enter the body only through the ingestion of food, accumulate in the bones, and are not greatly subject to postmortem changes. Therefore, the analysis of the accumulation pattern of bones such as femur, humerus, and tibia can reveal information on the long-term diet of an individual (Ambrose and Krigbaum, 2003). The evaluation of the results will then be more valid if they are supported by the data gained from archaeozoology, paleobotany, paleopathology, etc.

Among the oligoelements, while strontium, magnesium, and manganese are indicators of vegetarian diet, zinc and copper $(\mathrm{Cu})$ are linked to the consumption of animal proteins (Giorgio et al., 2005). Strontium is taken in by the plants directly from the environment (e.g. soil) and is reduced in the trophic levels from the bottom to the top. The living omnivore therefore displays elemental concentration levels in the range of $150-400 \mu \mathrm{g} / \mathrm{g}$ which is between the values of herbivore $(400-500 \mu \mathrm{g} / \mathrm{g})$ and carnivore $(150-400 \mu \mathrm{g} / \mathrm{g})$ (Giorgi et al., 2005; Busetto et al., 2008). Sr/Ca ratio also follows the same pattern, and the rate is lower in the carnivore than in the herbivore. Thus, values higher than 0.57 point to a vegetable rich diet (Giorgio et al., 2005). Zinc is abundant in marine sources, red meats, dairy products, and some vegetables such as nuts and legumes. As an omnivore, humans have $\mathrm{Zn}$ values in a range of $120-200 \mu \mathrm{g} / \mathrm{g}$, which is similarly placed at midrange between herbivore $(90-150 \mu \mathrm{g} / \mathrm{g})$ and carnivore $(175-250 \mu \mathrm{g} / \mathrm{g})$. Moreover, $\mathrm{Zn} / \mathrm{Ca}$ value is used for classifying the type of current economy of the investigated population ( $>0.60$ for rich economy, $<0.35$ for poor in protein, and between 0.60-0.35 for mixed diet) (Fornaciari, et al., 1984; Giorgio et al., 2005). As an indicator of past nutrition, $\mathrm{Mg}$ concentration in bones is linked to vegetable consumption, particularly cereals (Giorgi, et al., 2005). Modern values for tibia bone are reported as $5514 \pm 1246.6 \mathrm{ppm}$, and for vertebra in a range of $1560 \pm 46-6704 \pm 27 \mathrm{ppm}$. The other indicator of animal sources is copper, which is abundant in offal and legumes, and fresh bone value is reported as lower than $10 \mathrm{ppm}$. The optimal values of $\mathrm{Mg} / \mathrm{Ca}$ and $\mathrm{Cu} / \mathrm{Ca}$ are offered as 8.86 and between 0.15-0.20, respectively (Giorgio et al., 2005). Higher Mn (for fresh bone $<10 \mathrm{ppm}$ ) values refer to more vegetable consumption since it is abundant in plants (Giorgio et al., 2005; Corti et al., 2013) as well. $\mathrm{Pb}$ is an element of extremely high interest due to its toxicological characteristics; it is introduced in the human body through diet and breathing, and it plays an important role in detecting environmental pollution (Zapata et al., 2006).

The elemental status of buried bones can also be affected by the surrounding soil or groundwater (Hedges, 2002). The trace elements can accumulate on the surface of the hydroxyapatite, or be incorporated into the hydroxyapatite matrix (Elliott and Grime, 1993). The degree of diagenesis can be determined by different methods such as calculating $\mathrm{Ca} / \mathrm{P}$ ratio (2.16 as a reference value) and analyzing soil samples to rule out the possibility of migration of elements from the bone to the soil (Nelson and Sauer, 1984).

Several techniques are used to evaluate the apatite elemental composition of archaeological bone samples, such as atomic absorption spectroscopy (AAS), atomic emission spectroscopy (AES), Inductively Coupled Plasma-Mass Spectrometer (ICP-MS), and neutron activation analysis (NAA). X-ray fluorescence (XRF) spectrometry, which permits fast multielement detection, was used for this study (Sandford, 1992). 
The aim of the study is to obtain information on the dietary changes of the TepecikÇiftlik populations through different levels of the Neolithic Period. For this purpose the study focuses on strontium, zinc, copper, magnesium, and manganese as diet markers, and lead as a post-mortem contamination marker.

\section{Materials and Methods}

The site Tepecik-Çiftlik has been excavated by Erhan Bıçakçı from İstanbul University since 2000 (Bıçakç1, 2001). The oval shaped mound is located on Çiftlik plain which is; (1) $1.500 \mathrm{~m}$ above sea level; (2) formed by pumice and ash mixture; (3) about $300 \mathrm{~m}$ long by $170 \mathrm{~m}$ wide with $9.6 \mathrm{~m}$ height, and (4) situated in the volcanic Cappadocia region of Central Anatolia, within the boundaries of Niğde province, Turkey (Bıçakç1, 2001) (Fig. 1). Chronologically, the site can be divided into three main periods, namely Neolithic (c. 7500-6100 BC), Chalcolithic (c. 6100-5800), and Late Roman-Early Byzantine, comprising a total of 14 levels, according to the latest update (Fig. 1). The extensive excavations revealed more than 170 individuals from Pottery Neolithic Period dated to the 7th millennium cal. BC (Çakan, 2013). The Pottery Neolithic Period of the site covers seven levels from nine to two, but the skeletons were unearthed from the 5th, 4th, and 3rd levels. The exact date of the mentioned levels is between 6800 and $6100 \mathrm{cal}$. BC according to C14 dating (Çakan, 2013).

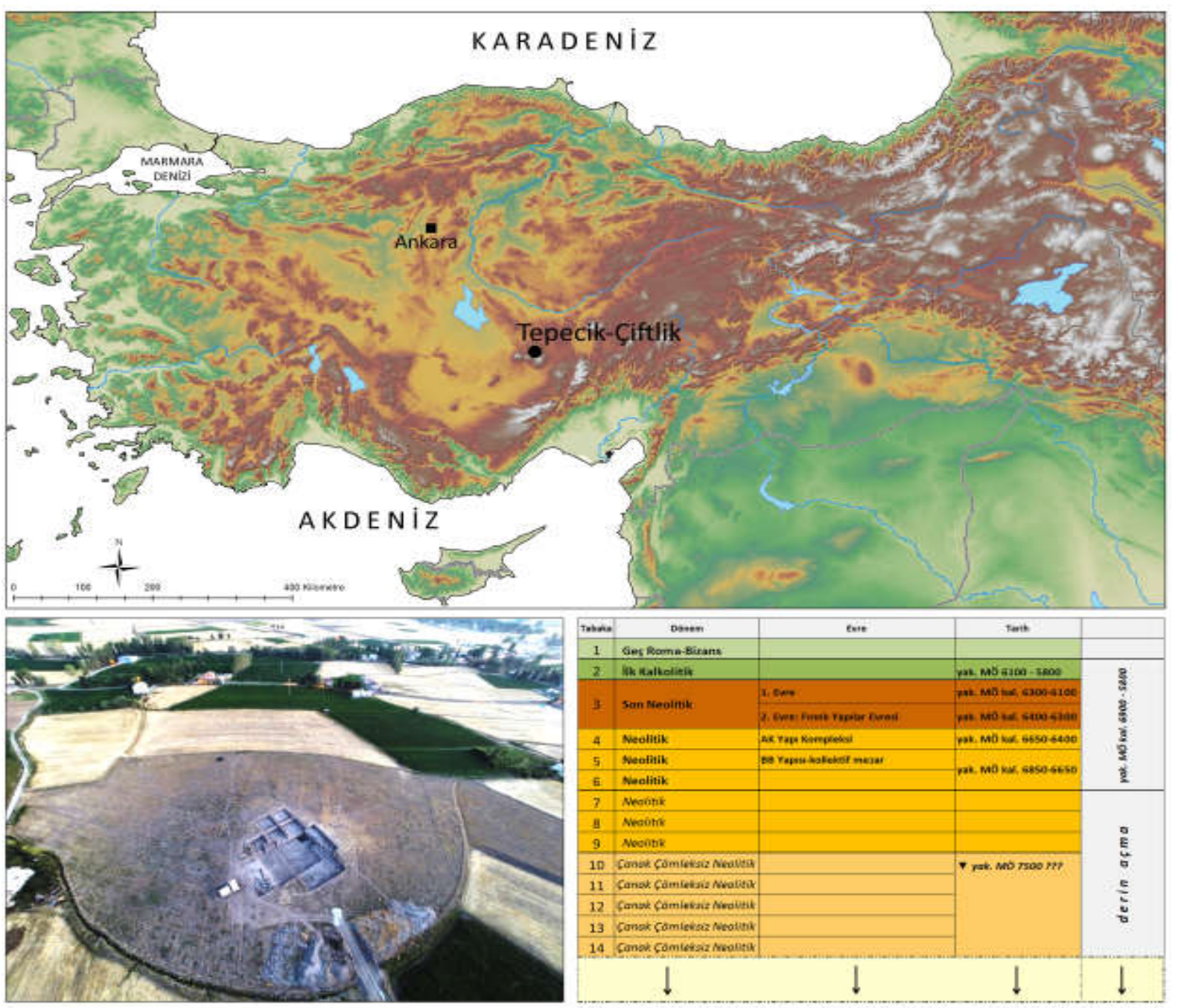

Figure 1: Location of the Neolithic Period Tepecik-Çiftlik settlement (upper part), an overview from höyük (lower left), and the stratification of the settlement (lower right).

Level 5 revealed the structure BB which was used as a collective burial site for primary and secondary burial, and it is estimated to have had at least 42 individuals. The great majority 
of the inhumations belonging to Level 4 were gathered from the AY and BA sites of the AK architectural complex (the excavation has not yet been completed). However, the burials in Level 3 are found either on the open regions of the settlements or near buildings.

The Tepecik-Çiftlik settlement is located near very important obsidian resources which have been used intensively since Paleolithic times (Bıçakçı et al., 2012). It is well known that this important commodity from Göllüdağ or other resources nearby was transported as far as, for example, Cyprus and the Levant (Balkan-Atlı and Binder, 2012; Binder, 2002; Şevketoğlu, 2006, 2008). So, Tepecik-Çiftlik can be a crucial site in helping us better understand Neolithic social behavior and human mobility, as well as relations between different groups (Büyükkarakaya et al., 2012; Büyükkarakaya and Erdal, 2014a, b).

Until now, more than one hundred graves and a collective burial site were unearthed in the field and various treatments to the deceased were identified (Büyükkarakaya et al., 2009; Büyükkarakaya et al., 2012). A total of 67 well preserved human bone samples were selected from the osteologically examined skeletons from Tepecik-Çiftlik. Femurs $(n=49)$ were selected for analysis whenever possible, but due to postmortem loss of femur in some cases other bones such as humerus $(n=11)$, tibia $(n=6)$, and ulna $(n=1)$ occasionally had to be selected as alternatives to femurs. Bone fragments of $4-5 \mathrm{~cm}$. in length were sawed from the mid-shaft of each bone in order to include a representative portion of cortical bone from periosteal and endosteal surfaces.

The age and sex of all individuals had previously been determined through standard osteological methods. The sex estimation of the skeleton was based on the morphological features of the skull, pelvic girdle, and long bones (Buikstra and Ubelaker, 1994). The skeletal features used for determination of age at death for adults are cranial suture closure, sternal rib ends, the pubic symphysis, and the auricular surfaces of the ilium (İşcan et al., 1984, 1985; Lovejoy et al., 1985; Meindle and Lovejoy, 1985; Buikstra and Ubelaker, 1994). The age of subadults was assigned using dental development (Ubelaker, 1989). The skeletal samples belonged to individuals of both sex and ages ranging from newborn to old adulthood.

The animal bones used in this study come from different levels of the settlement and comprise herbivores $(\mathrm{n}=15)$ such as cattle $($ Bos $)$, red deer (Cervus elaphus), goat (Capra), and sheep (Ovis), and omnivores ( $\mathrm{n}=3$ ) like pig (Sus).

After removal of the visible contaminants, bone samples were ultrasonically washed with distilled water for at least 15 minutes and then were placed in an oven (at $105 \mathrm{C}$ ) for a one-day period. Next, the specimens were burned at $600 \mathrm{C}$ for three hours. Finally, they were grounded up using a porcelain mortar and pestle.

The major and trace element compositions of the samples were analyzed by polarized energy dispersive X-ray fluorescence spectroscopy (PED-XRF) (Salmon, 1970). A Spectro XLAB 2000 PED-XRF spectrometer which was equipped with a Rh anode X-ray tube, $0.5 \mathrm{~mm}$ Be side window was used. The detector of the spectrometer is $\mathrm{Si}(\mathrm{Li})$ by liquid $\mathrm{N}_{2}$ cooled with resolution of $<150 \mathrm{eV}$ at $\mathrm{Mn} \mathrm{K \alpha}, 5000 \mathrm{cps}$. The XRF analysis was done at the Ankara University Earth Sciences Application and Research Center-YEBIM.

Four soil samples were gathered from the burial environment of the skeletal remains at the same depth. The elemental compositions of soil samples were analyzed in a method similar to that used for the bones by PED-XRF. The soil samples were additionally analyzed for $\mathrm{pH}$.

The results were statistically described by mean value, standard deviation (SD), measurement range (minimum and maximum values), and coefficient variation (CV) for each element in the studied groups. ANOVA $(p=0.05)$ was performed using Microsoft Excel 2012. In order to discover the relationship among the elemental status of three time groups, principal 
component analysis (PCA) and discriminate analysis (DA) were performed. The statistical analysis was done by using XLSTAT software.

\section{Results}

The supervised score plot (adults vs. subadults) obtained by the first PCA model explains total variance in the data set with $64 \%$ value in the first two functions (F1 and F2, Fig. 2 ). The variation is at the $\mathrm{X}$-axis. While most of the adults (red squares) centralized on the negative quarter, the subadults (green triangles), and few adults escape from the group towards the positive part. The loading plot shows that the subadults have higher $\mathrm{Mn}, \mathrm{Sr}, \mathrm{Cu}, \mathrm{Zn}$, and $\mathrm{Pb}$ values than adults (Fig. 2). ANOVA found statistically significant differences for $\mathrm{Mn}, \mathrm{Cu}, \mathrm{Zn}$, and $\mathrm{Sr}(p$ values: $\mathrm{Cu}=0.008, \mathrm{Mn}=0.036, \mathrm{Zn}=5 \mathrm{E}-07, \mathrm{Sr}=2 \mathrm{E}-05)$ between adults and subadults.
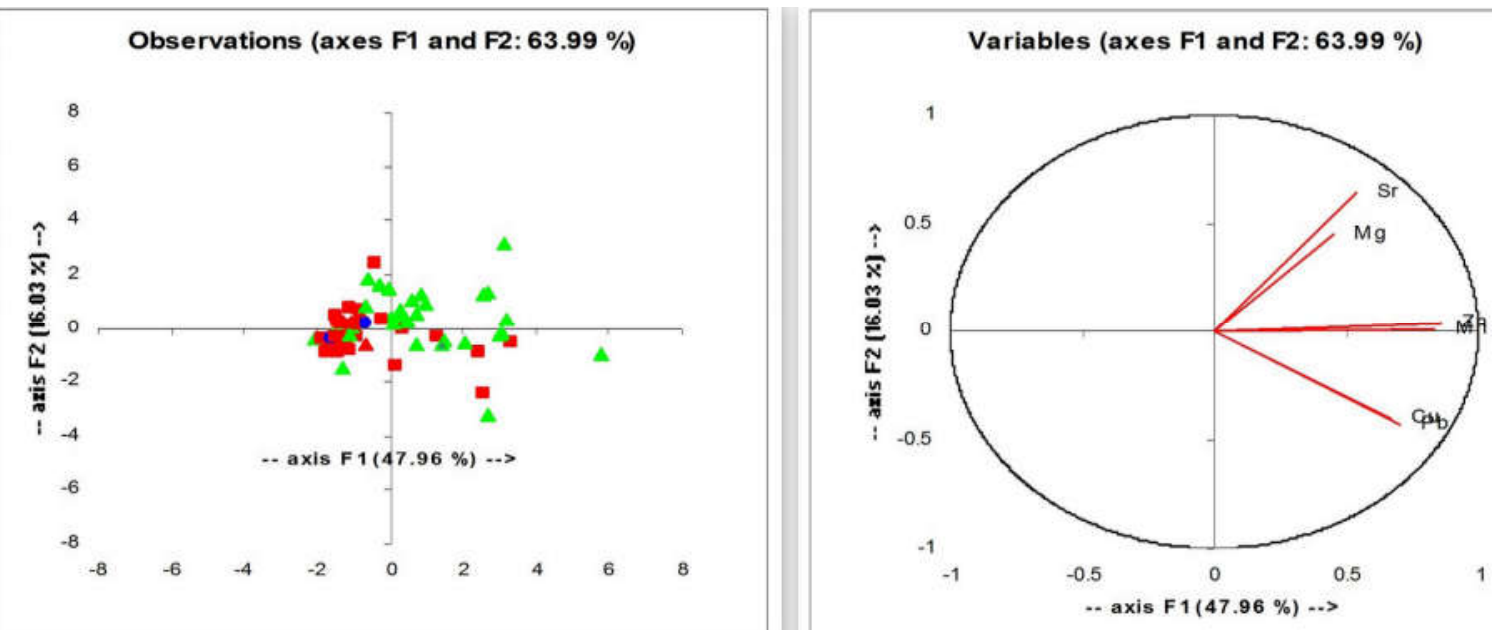

Figure 2: Score (on the left) and loading (on the right) plots for the PCA model using adults' and subadults' data: subadult $=$ green triangles, adult $=$ red squares .

The PCA was also done among the adult individuals with respect to the time levels (5th, 4th, and 3rd levels of Neolithic Period). The score plot explains $73 \%$ of variance with two components (Fig. 3). The variance is along the X-axis again. The individuals from three levels mainly formed a group, but some individuals behaved separately from the group. The loading plot points to two different groups of variables (Fig. 3). $\mathrm{Mg}, \mathrm{Mn}, \mathrm{Cu}, \mathrm{Zn}$, and $\mathrm{Pb}$ show high negative loading (F1, 54.5\%). However, Sr was important for the construction of F2 $(18.5 \%$, high positive loadings). Mg accumulation stays the same through the three levels, whereas $\mathrm{Mn}$, $\mathrm{Zn}, \mathrm{Cu}$, and $\mathrm{Pb}$ reached maximum concentration at Level 4. Sr is higher in Level 5 for adult individuals. In the case of $\mathrm{Mn}$ and $\mathrm{Pb}$, ANOVA found statistically important relations among the levels ( $p$ values: $\mathrm{Mn}=0.027, \mathrm{~Pb}=0.021$ ) 

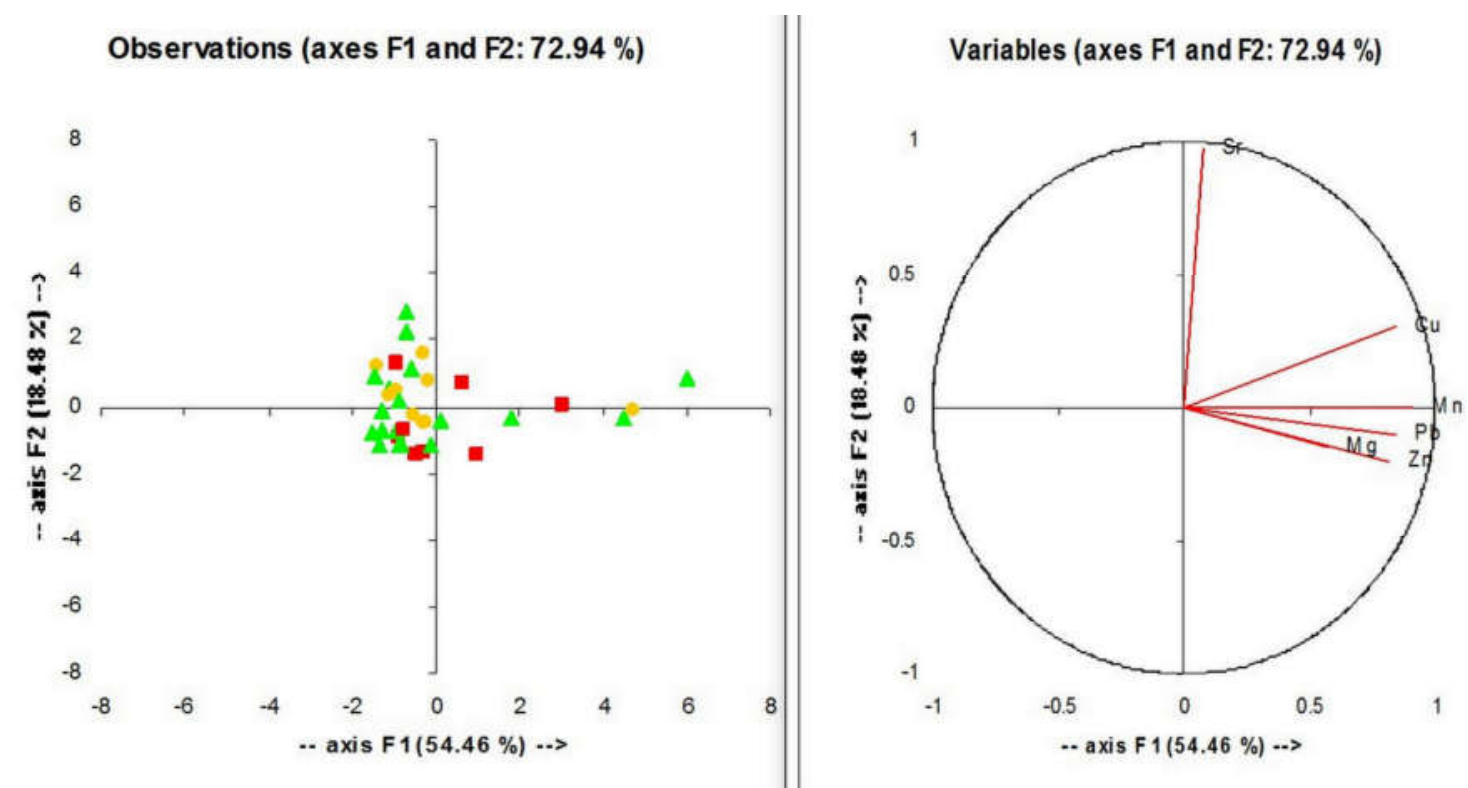

Figure 3: Score (on the left) and loading (on the right) plots for the PCA model using adults' data from the different Levels: Level $3=$ green triangles, Level $4=$ red squares, Level $5=$ yellow circle.

Discriminant analysis (DA) was performed among the adult individuals from three levels as well (Fig. 4). The analysis correctly classified 100\% of the samples. Most of the samples $(\mathrm{n}=15)$ belonging to Level 3 stayed correctly in the group (Fig. 4). Only two samples from Level 3 grouped in Level 5. Half of the samples from Level $5(n=4)$ and Level $4(n=5)$ were transferred to Level 3. The other halves were grouped with their own level groups.
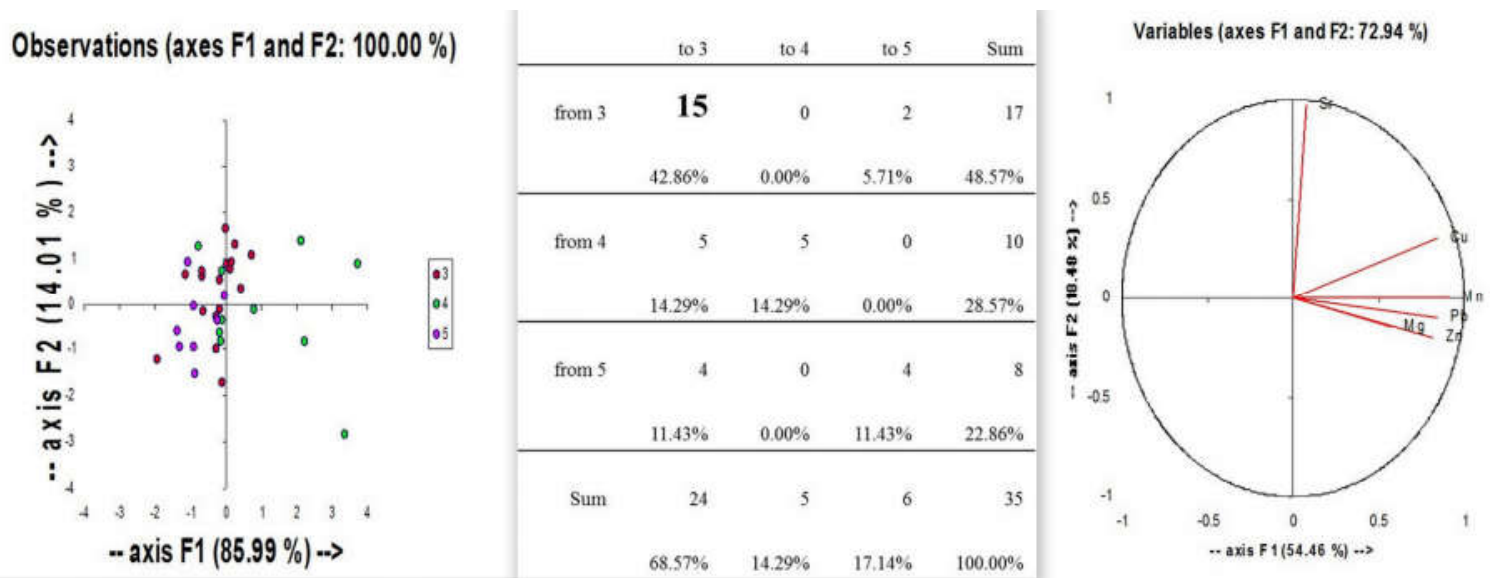

Figure 4: Observation plot (left), the confusion matrix of DA (middle) and score plot of PCA (right) using adults' data from the different Levels.

The mean value of $\mathrm{Ca}$ is $346.65 \mathrm{mg} / \mathrm{g}$ for the whole group. ANOVA revealed a statistically significant relation between adults and subadults $(p=0.00025)$. Considering $\mathrm{Ca}$ concentration of adults from different levels, ANOVA did not produce a significant relation ( $p$ $=0,708)$. However, there was a significant relation between male and female subgroups $(p=$ $0.0265)$. No statistically significant relation was found among the sub-adults from different levels $(p=0,602)$.

ANOVA was also carried out using metal/Ca ratios from different subgroups. It confirmed that $\mathrm{Cu} / \mathrm{Ca}(p=0.00636), \mathrm{Sr} / \mathrm{Ca}(p=1.50 \mathrm{E}-08), \mathrm{Zn} / \mathrm{Ca}(p=1.16 \mathrm{E}-07), \mathrm{Mg} / \mathrm{Ca}(p=$ $6.02 \mathrm{E}-05)$, and $\mathrm{Mn} / \mathrm{Ca}(p=0.01262)$ distinguish adults and subadults. Concerning the adults from the different levels, $\mathrm{Pb} / \mathrm{Ca}(p=0.0251)$ and $\mathrm{Mn} / \mathrm{Ca}(p=0.0240)$ ratios were statistically important. The $\mathrm{Mg} / \mathrm{Ca}$ ratio between female and male was statistically significant $(p=0.0257)$. 
Among the subadults from the different levels, only the $\mathrm{Mg} / \mathrm{Ca}$ ratio was statistically important $(p=0.0445)$.

In general, samples from Tepecik-Çiftlik, whether human or faunal, adult or subadult, yielded $\mathrm{Ca} / \mathrm{P}$ ratios between 2.84 and 2.96 , significantly above those observed in normal conditions (Table 1). The soil average $\mathrm{Ca} / \mathrm{P}$ ratio was 6.57 .

Table 1: $\mathrm{Ca} / \mathrm{P}$ ratios of different sub-groups.

\begin{tabular}{|c|c|c|c|}
\hline Group/Element & $\mathrm{Ca}(\mathrm{mg} / \mathrm{g})$ & $\mathrm{P}(\mathrm{mg} / \mathrm{g})$ & $\mathrm{Ca} / \mathrm{P}$ \\
\hline \multicolumn{4}{|l|}{ Infant } \\
\hline $\mathrm{N}$ & 19 & 19 & 19 \\
\hline $\mathrm{X}$ & 324.54 & 114.38 & 2.84 \\
\hline sd. & 11.05 & 11.05 & 0.08 \\
\hline Min. & 268.84 & 92.20 & 2.73 \\
\hline Max. & 375.07 & 137.55 & 3.02 \\
\hline $\begin{array}{l}\text { cv. } \\
\text { Child }\end{array}$ & 3.40 & 9.66 & 2.80 \\
\hline $\mathrm{N}$ & 13 & 13 & 13 \\
\hline $\mathrm{X}$ & 345.40 & 121.90 & 2.84 \\
\hline $\mathrm{Sd}$. & 22.44 & 11.61 & 0.13 \\
\hline Min. & 313.09 & 104.29 & 2.71 \\
\hline Max. & 381.86 & 144.10 & 3.09 \\
\hline cv. & 6.5 & 9.52 & 4.58 \\
\hline \multicolumn{4}{|l|}{ Adult } \\
\hline $\mathrm{N}$ & 35 & 35 & 35 \\
\hline $\mathrm{X}$ & 358.92 & 126.92 & 2.84 \\
\hline sd. & 27.72 & 11.68 & 0.16 \\
\hline Min. & 272.90 & 125.21 & 2.57 \\
\hline Max. & 395.51 & 146.98 & 3.54 \\
\hline cv. & 7.72 & 9.20 & 5.71 \\
\hline Reference & $\sim 380$ & $\sim 180$ & $\sim 2.16$ \\
\hline \multicolumn{4}{|l|}{ Herbivore } \\
\hline $\mathrm{N}$ & 14 & 14 & 14 \\
\hline $\mathrm{X}$ & 369.75 & 130.98 & 2.83 \\
\hline Sd. & 19.71 & 7.89 & 0.07 \\
\hline Min. & 338.38 & 117.69 & 2.75 \\
\hline Max. & 410.38 & 142.22 & 3.06 \\
\hline $\mathrm{cv}$ & 5.33 & 6.02 & 2.55 \\
\hline \multicolumn{4}{|l|}{ Omnivore } \\
\hline $\mathrm{N}$ & 3 & 3 & 3 \\
\hline $\mathrm{X}$ & 379.12 & 128.36 & 2.96 \\
\hline Sd. & 8.23 & 4.05 & 0.15 \\
\hline Min. & 369.63 & 125.63 & 2.78 \\
\hline Max. & 384.43 & 133.01 & 3.06 \\
\hline cv. & 2.17 & 3.16 & 5.23 \\
\hline \multicolumn{4}{|l|}{ Soil } \\
\hline $\mathrm{N}$ & 4 & 4 & 4 \\
\hline$X$ & 141.34 & 36.29 & 6.57 \\
\hline Sd. & 120.07 & 51.21 & 3.66 \\
\hline Min. & 53.07 & 10.08 & 2.81 \\
\hline Max. & 317.53 & 113.11 & 11.30 \\
\hline cv. & 84.95 & 141.12 & 55.63 \\
\hline
\end{tabular}

The $\mathrm{pH}$ values of four soil samples were measured as $7.02,7.23,7.90$, and 8.01 with a mean of 7.54 .

\section{Discussion}

\section{Diagenesis Evaluation}

General issues on the interpretation of trace element analysis conducted on archaeological skeletal remains mainly arise from the process of diagenesis (Szostek et al., 2005). Depending on the characteristics of the burial site and surrounding soil type and its content, post-mortem alterations can affect the chemical profile of osseous materials to an 
extent. The extent of diagenesis is assessed by the calcium-phosphorus ratio that indicates bone integrity (Zapata et al., 2006; Shafer et al., 2008; János et al, 2011). However, even in cases where a native $\mathrm{Ca} / \mathrm{P}$ ratio $(\sim 2.16)$ can be measured for ancient bones, some studies still refer to significant bone compositional changes (e.g. Fabing and Hermann, 2002). Selection of archaeological bone is very important for reducing the impact of diagenesis (Price et al., 1992). A study conducted on the Tepecik-Çiftlik bone samples revealed that the post mortem alterations affected the different bone types in different extent (Sevdin, 2017). Femur displayed less alteration among rib, metacarpal/metatarsal, and femur of the same individual, which was chosen for the analysis.

The bone $\mathrm{Ca} / \mathrm{P}$ ratios calculated for Tepecik-Çiftlik sub-samples (Table 1) are higher than the values reported from the sites that were evaluated as minimally changed historic bone remains (for İkiztepe adults 2.22, Özdemir, 2008; for two ancient cemeteries from Northeastern Hungary, 2.20 and 2.36, János et al, 2011). Besides, the values are higher than the range of ratios that were proposed by Zapata et al. (2006) as thresholds of significant diagenetic process (2.30 to 2.50). Based on the comparisons, it can be concluded that the studied bone samples, in general, have been subjected to significant postmortem alterations. No significant differences were detected among the levels, suggesting that a similar degree of diagenesis affected whole samples.

The anomalous $\mathrm{Ca} / \mathrm{P}$ values could have occurred due to the surrounding soil $\mathrm{pH}$. However, the present study has shown that the $\mathrm{pH}$ of soil is approximately neutral. The neutrality of the soil may be considered as an indicator of the good preservation state of the bones (Özdemir, 2008; Zapata et al., 2006). But, according to Nicholson (page: 514, 1996), "the $\mathrm{pH}$ alone is insufficient as a predictor of skeletal preservation," so the elemental content of soil was determined and compared to that of the bones. In addition, fresh bone levels of the elements and comparative measurements from animal bones of known trophic position help us decide whether the element accumulation is biogenic or diagenic in origin.

Compared to fresh bone values, the mean accumulations of $\mathrm{Sr}$ in the adult individuals from three levels (Table 2) are high. However, the mean values are not higher than 1000ppm, an indicator which was previously proposed as a marker of diagenesis by Kyle (1986) and Radosevich (1993). The concentrations of Sr also exhibit low variation (CV < 14\%), indicating a single source for accumulation. Moreover, herbivores show higher mean value than humans (Table 3).

Table 2: Element concentrations of adults from different Levels.

\begin{tabular}{|c|c|c|c|c|c|c|}
\hline & $\mathrm{Mg}(\mathrm{mg} / \mathrm{g})$ & $\mathrm{Mn}(\mathrm{mg} / \mathrm{g})$ & $\mathrm{Cu}(\mathrm{ppm})$ & $\mathrm{Zn}(\mathrm{ppm})$ & $\mathrm{Sr}(\mathrm{ppm})$ & $\mathrm{Pb}(\mathrm{ppm})$ \\
\hline \multicolumn{7}{|c|}{ Level 3} \\
\hline \multicolumn{7}{|l|}{ n (17) } \\
\hline $\mathrm{x}$ & 0.49 & 0.19 & 3.63 & 149.52 & 705.56 & 2.89 \\
\hline $\mathrm{sd}$ & 0.03 & 0.30 & 5.27 & 60.18 & 103.92 & 2.10 \\
\hline min. & 0.43 & 0.03 & 0.40 & 93.50 & 592.90 & 1.00 \\
\hline $\max$. & 0.57 & 1.26 & 21.90 & 290.30 & 981.50 & 10.30 \\
\hline cv (\%) & 6.25 & 153.59 & 145.08 & 40.25 & 14.73 & 72.73 \\
\hline \multicolumn{7}{|l|}{ Level 4} \\
\hline \multicolumn{7}{|l|}{ n (10) } \\
\hline $\mathrm{x}$ & 0.49 & 0.66 & 5.43 & 185.70 & 681.29 & 6.22 \\
\hline sd & 0.03 & 0.76 & 5.02 & 52.99 & 70.84 & 4.33 \\
\hline $\min$. & 0.47 & 0.02 & 0.40 & 121.60 & 592.20 & 1.00 \\
\hline $\max$. & 0.53 & 1.82 & 12.50 & 288.70 & 817.00 & 13.40 \\
\hline cv $(\%)$ & 5.64 & 115.60 & 92.46 & 28.53 & 10.40 & 69.56 \\
\hline Level 5 & & & & & & \\
\hline
\end{tabular}




\begin{tabular}{|c|c|c|c|c|c|c|}
\hline \multicolumn{7}{|l|}{ n (8) } \\
\hline $\mathrm{x}$ & 0.48 & 0.04 & 3.81 & 152.56 & 732.70 & 2.71 \\
\hline sd & 0.02 & 0.02 & 2.43 & 26.40 & 68.00 & 0.59 \\
\hline min. & 0.45 & 0.01 & 1.10 & 117.80 & 634.20 & 1.80 \\
\hline $\max$ & 0.50 & 0.08 & 6.60 & 195.80 & 823.00 & 3.40 \\
\hline $\mathrm{cV}$ & 4.21 & 66.37 & 63.76 & 17.31 & 9.28 & 21.63 \\
\hline
\end{tabular}

In the case of $\mathrm{Pb}$, the mean value of Tepecik-Ciftlik adults is lower than the reference values (<50ppm, González-Reimers et al., 2003; Martínez-García et al., 2005; Zapata et al., 2006; Özdemir et al., 2010). There are no signs that burial gifts or body pigments existed to explain the observed accumulations. Thus, the source must be from the sediments. The lead content of soil is higher than in the bones, indicating diagenesis. The high coefficient of variation due to the different burial conditions also supports this observation. Although the $\mathrm{Cu}$ level is in the biogenic range, the soil level is higher than the bone level (Table 2 and 3). The same evaluation is valid for Mn (Table 2 and 3) since Mn in bone levels are lower than in the soil and have high coefficient variation values. For zinc, the adult level is higher than in the soil and herbivores, supporting biogenic accumulation in bones (Table 2 and 3). Magnesium represents biogenic rank and low variation. Thus, seemingly $\mathrm{Sr}, \mathrm{Zn}$, and $\mathrm{Mg}$ levels are important for this study.

Table 3: Element concentrations in general.

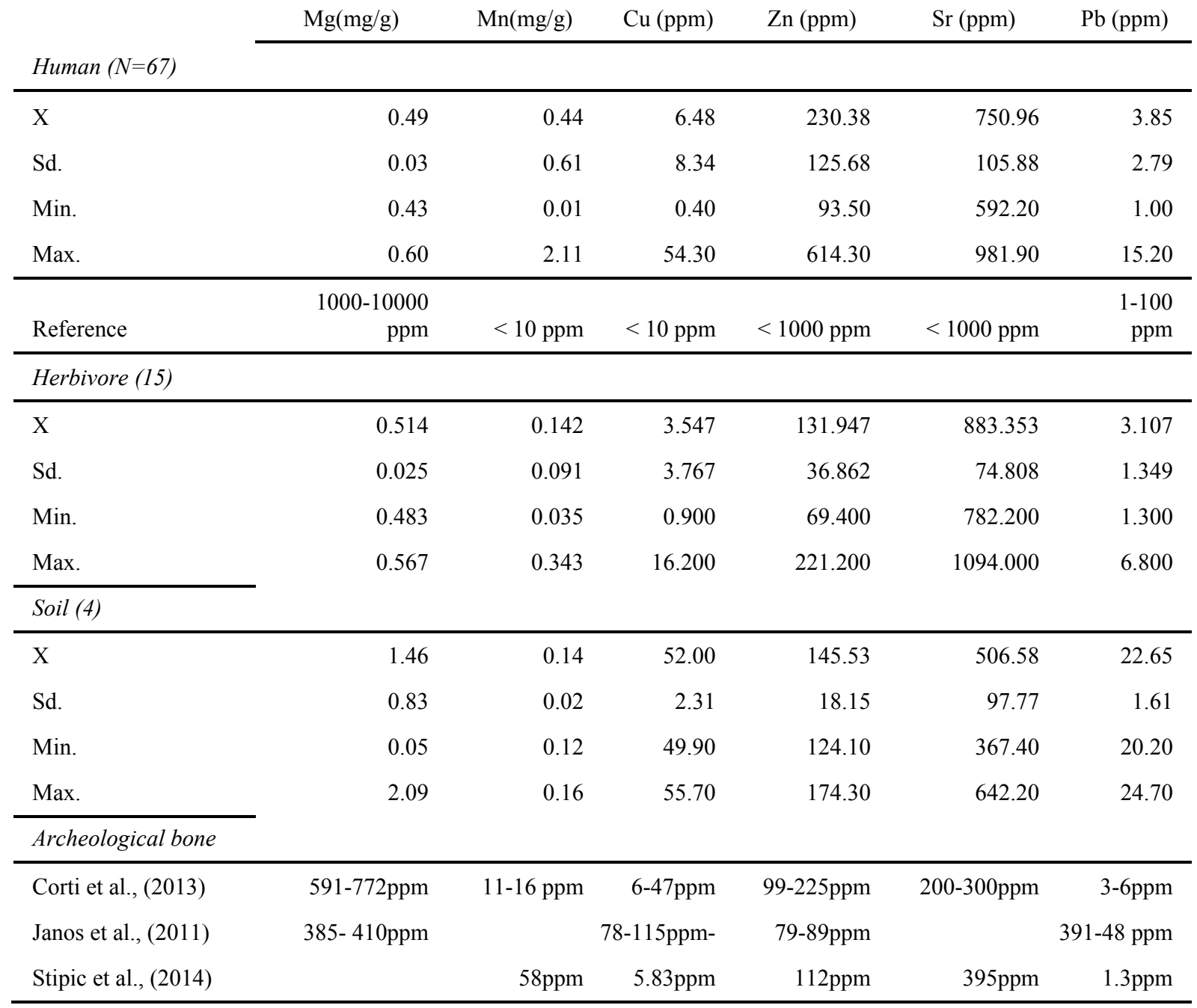

Bivariate analysis of elements with calcium was then used to normalize the element concentration, based on the principle that, if diagenesis had occurred, it affected both the 
calcium matrix and trace elements in the same way (Corti et al., 2013; Busetto et al., 2008; Giorgi et al., 2005).

\section{Diet Reconstruction}

The statistical elaboration of the obtained data refers to a significant difference between adults and subadults. Previous research proposed that the different biogenic accumulations of some elements such as $\mathrm{Sr}$ and $\mathrm{Zn}$, due to the development of digestive tract, cause higher levels in juveniles (Corti et al., 2013; Mays, 2003; Beck, 1985; Lambert et al., 1984). However, the finding can also refer to the higher susceptibility of subadult bones to diagenesis than adults (Sandford, 1992; Zapata et al., 2006).

Taking in account the average value of $\mathrm{Sr} / \mathrm{Ca}$ ratio reported by Giorgi et al. (2005), mean values of Tepecik-Çiftlik adults from the three levels suggest a vegetable-rich diet (Table 4). Concerning the protein components of the diet, $\mathrm{Zn} / \mathrm{Ca}$ values pointed to a protein-rich diet and rich subsistence economy for Level 4 adults based on the proposed values by Giorgi et al. (2005) and Busetto et al. (2008) (Table 4). However, the same comparisons support a mixed diet and poor economy for adult individuals from Levels 3 and 5. According to the values reported by Giorgi et al. (2005), mean values for $\mathrm{Mg} / \mathrm{Ca}$ and $\mathrm{Cu} / \mathrm{Ca}$ found in adults from three levels are far from the optimal reference parameters (Table 4). Concerning $\mathrm{Mg} / \mathrm{Ca}$ which is the indicator of the importance of plant food, a significant statistical relation between male and female individuals, regardless of level, points to the importance of plant sources in diet for females in Tepecik-Çiftlik. For the $\mathrm{Cu} / \mathrm{Ca}$ mean values, the higher means of Level 4 adults point to the relative importance of offal and legumes in their diet (Table 4).

The relationship between the studied elements, and that of the different element composition patterns with the levels, were visualized with PCA and DA to understand the results of bivariate analysis better. PCA and DA performed on adults indicate a clear separation of the individuals of Level 3 from those in Levels 4 and 5 (Fig. 4). Our evidence asserts that $\mathrm{Sr}$ distinguished Level 3 while the other elements distinguished Levels 4 and 5. This can be evaluated as a shift from meat consumption and rich subsistence economy in the lower levels to more vegetable consumption and poor subsistence economy in the upper level. Concerning subadults, no differences were determined in regard to levels.

Ongoing zooarchaeological and archaeobotanical studies provide some important clues about subsistence economy and lifestyle (personal communication with Can Yumni Gündem). According to zooarchaeological studies, Neolithic people at Tepecik-Çiftlik consumed both domesticated and wild animals, and the amount of wild animals increased towards the end of the Neolithic period (Bıçakçı et al., 2007). The most abundant animal bones in the settlement belong to sheep/goat (Ovicaprid), cattle (Bos), horse (Equus), red deer (Cervus elaphus), boar (Sus), bear (Ursus), rodents, rabbit, and a few bird species (Bıçakçı et al., 2007). It seems that, depending on suitable climatic and environmental conditions, the Neolithic people at TepecikÇiftlik could have had the chance to additionally consume different kinds of plants. Numerous ground stones found in primary and secondary usage, along with plenty of seeds of various plants, and a lot of storage units, indicate that plant sources had an important place in the diet (Bıçakç1 et al., 2007). Indeed, ongoing research on the archaeobotanical remains show that wheat (Triticum turgidum dicoccum), barley (Hordeum vulgare), pea (Cicer arietinum), bitter vetch (Vicia ervilia), and lentil (Lens culinaris) were cultivated in the settlement (pers. comm. with Ceren Çilingir İpek). Other data from bioarchaeological studies also show that Neolithic people at Tepecik-Çiftlik had relatively high caries rate $(10.0 \%)$, a finding which has been interpreted as being due to the importance of cereals in the diet (Büyükkarakaya and Erdal, 2014a). 
Table 4: Element/Ca ratio of different sub-groups (sex of seven adults did not estimated)

\begin{tabular}{|c|c|c|c|c|c|c|c|}
\hline Adult (n=36) & $\mathrm{Ca}(\mathrm{mg} / \mathrm{g})$ & $\mathrm{Cu} / \mathrm{Ca}$ & $\mathrm{Sr} / \mathrm{Ca}$ & $\mathrm{Zn} / \mathrm{Ca}$ & $\mathrm{Mg} / \mathrm{Ca}$ & & $\mathrm{In} / \mathrm{Ca}$ \\
\hline $\mathrm{X}$ & 358.9156 & 0.0000 & 0.0020 & 0.0005 & 0.0000 & 0.0014 & 0.0008 \\
\hline Sd. & 27.7166 & 0.0000 & 0.0002 & 0.0002 & 0.0000 & 0.0001 & 0.0014 \\
\hline Min. & 272.4897 & 0.0000 & 0.0016 & 0.0003 & 0.0000 & 0.0011 & 0.0000 \\
\hline Max. & 395.5103 & 0.0001 & 0.0026 & 0.0010 & 0.0000 & 0.0018 & 0.0056 \\
\hline $\mathrm{cv}$ & 7.7223 & 111.8869 & 12.6844 & 34.7232 & 85.6802 & 7.9888 & 180.2778 \\
\hline \multicolumn{8}{|c|}{ Subadult (n=31) } \\
\hline $\mathrm{X}$ & 331.18361 & 0.00003 & 0.00244 & 0.00095 & 0.00001 & 0.00150 & 0.00193 \\
\hline Sd. & 26.65840 & 0.00003 & 0.00034 & 0.00046 & 0.00001 & 0.00013 & 0.00224 \\
\hline Min. & 268.84409 & 0.00000 & 0.00170 & 0.00034 & 0.00000 & 0.00129 & 0.00002 \\
\hline Max. & 381.85725 & 0.00017 & 0.00312 & 0.00186 & 0.00005 & 0.00180 & 0.00783 \\
\hline $\mathrm{cv}$. & 8.04943 & 115.75753 & 13.75876 & 48.02861 & 64.19295 & 8.76379 & 116.00530 \\
\hline
\end{tabular}

Female $(n=16)$

\begin{tabular}{lrrrrrrr}
\hline X & 347.27899 & 0.00001 & 0.00198 & 0.00046 & 0.00001 & 0.00143 & 0.00129 \\
Sd. & 30.92074 & 0.00001 & 0.00023 & 0.00018 & 0.00001 & 0.00012 & 0.00188 \\
Min. & 272.48967 & 0.00000 & 0.00163 & 0.00029 & 0.00000 & 0.00006 \\
Max. & 388.29064 & 0.00004 & 0.00241 & 0.00098 & 0.00005 & 0.00177 \\
cv. & 8.90372 & 114.69036 & 11.80185 & 37.91633 & 86.69935 & 8.09896 & 145.66012 \\
Male (n=13) & & & & & & & \\
\hline X & 368.5258427 & $1.26294 \mathrm{E}-05$ & 0.001942686 & 0.000462293 & $1.00894 \mathrm{E}-05$ & 0.001328557 & 0.000572169 \\
Sd. & 21.67636965 & $1.51812 \mathrm{E}-05$ & 0.000282501 & 0.0001756 & $9.04753 \mathrm{E}-06$ & $9.3614 \mathrm{E}-05$ & 0.000895146
\end{tabular}


Table 4: Element/Ca ratio of different sub-groups (sex of seven adults did not estimated)

$\begin{array}{lllllllll}\text { Min. } & 325.0289995 & 2.62413 \mathrm{E}-06 & 0.001590067 & 0.000299579 & 2.75601 \mathrm{E}-06 & 0.001135017 & 9.48762 \mathrm{E}-05 \\ \text { Max. } & 394.5810594 & 5.69462 \mathrm{E}-05 & 0.002589724 & 0.000754862 & 2.99337 \mathrm{E}-05 & 0.001473494 & 0.003286237 \\ \text { cv. } & 5.881913055 & 120.2049187 & 14.54175593 & 37.984623 & 89.67332376 & 7.046292371 & 156.4479017\end{array}$

Adult vs. Level

\begin{tabular}{|c|c|c|c|c|c|c|c|c|}
\hline Level & & & & & & & & \\
\hline $\mathrm{X}$ & 357.2540128 & $1.01745 \mathrm{E}-05$ & 0.001987513 & 0.000426092 & $8.09305 \mathrm{E}-06$ & & 0.001382484 & 0.000551763 \\
\hline Sd. & 31.15533216 & $1.39339 \mathrm{E}-05$ & 0.000231131 & 0.000165959 & $5.58087 \mathrm{E}-06$ & & 0.000141099 & 0.000787778 \\
\hline Min. & 272.4896736 & $1.1818 \mathrm{E}-06$ & 0.001715594 & 0.000268306 & $2.75601 \mathrm{E}-06$ & & 0.001135017 & 7.04684E-05 \\
\hline Max. & 388.3621188 & $5.69462 \mathrm{E}-05$ & 0.002589724 & 0.000754862 & $2.67829 \mathrm{E}-05$ & & 0.001773768 & 0.003286237 \\
\hline $\mathrm{cv}$. & 8.720778784 & 136.9499811 & 11.62913335 & 38.94906023 & 68.95876539 & & 10.20619354 & 142.7747304 \\
\hline Level & & & & & & & & \\
\hline $\mathrm{X}$ & 359.3 & 24535 & $1.55222 \mathrm{E}-05$ & 0.001846338 & 0.00054947 & $1.68086 \mathrm{E}-05$ & 0.001390487 & 0.00190951 \\
\hline Sd. & 27.89 & 19023 & $1.53089 \mathrm{E}-05$ & 0.000247083 & 0.000181201 & $1.41138 \mathrm{E}-05$ & 8.06394E-05 & 0.002241781 \\
\hline Min. & 295.1 & 94917 & $1.10327 \mathrm{E}-06$ & 0.001590067 & 0.000383725 & $2.92118 \mathrm{E}-06$ & 0.001314893 & 5.81968E-05 \\
\hline Max. & 390.8 & 39914 & $4.23514 \mathrm{E}-05$ & 0.002380489 & 0.000978148 & 4.54007E-05 & 0.00158112 & 0.005554658 \\
\hline $\mathrm{cv}$. & 7.762 & 80667 & 98.62621775 & 13.38234917 & 32.97738327 & 83.96771237 & 5.799364494 & 117.4008443 \\
\hline Level & & & & & & & & \\
\hline $\mathrm{X}$ & 372.6 & 58503 & $1.02972 \mathrm{E}-05$ & 0.001976488 & 0.000408872 & $7.28273 \mathrm{E}-06$ & 0.001291151 & 9.93292E-05 \\
\hline Sd. & 17.90 & 19458 & $6.53538 \mathrm{E}-06$ & 0.000266105 & $6.30785 \mathrm{E}-05$ & $1.56403 \mathrm{E}-06$ & $2.19966 \mathrm{E}-05$ & 6.91603E-05 \\
\hline Min. & 353.5 & 03478 & $2.78122 \mathrm{E}-06$ & 0.001607274 & 0.000328607 & $5.09121 \mathrm{E}-06$ & 0.001264189 & $2.55589 \mathrm{E}-05$ \\
\hline Max. & 395.5 & 03264 & $1.71117 \mathrm{E}-05$ & 0.002308678 & 0.000495057 & $9.53767 \mathrm{E}-06$ & 0.001311913 & 0.000238279 \\
\hline
\end{tabular}


Table 4: Element/Ca ratio of different sub-groups (sex of seven adults did not estimated)

Subadult vs. Level

\begin{tabular}{|c|c|c|c|c|c|c|c|}
\hline \multicolumn{8}{|c|}{ Level $3(n=3)$} \\
\hline $\mathrm{X}$ & 332.1474229 & $2.02206 \mathrm{E}-05$ & 0.002535797 & 0.000891674 & $1.15561 \mathrm{E}-05$ & 0.001464275 & 0.002262638 \\
\hline $\mathrm{Sd}$. & 22.49129894 & $2.26266 \mathrm{E}-05$ & 0.000351998 & 0.000469826 & $5.20317 \mathrm{E}-06$ & 9.46644E-05 & 0.002373316 \\
\hline Min. & 305.2999465 & $1.57646 \mathrm{E}-06$ & 0.002005259 & 0.000344299 & 4.41409E-06 & 0.001314995 & $6.0238 \mathrm{E}-05$ \\
\hline Max. & 372.9219904 & $8.46153 \mathrm{E}-05$ & 0.00312152 & 0.001864157 & $2.08187 \mathrm{E}-05$ & 0.001608916 & 0.006342496 \\
\hline $\mathrm{cv}$. & 6.771480793 & 111.8989854 & 13.8811414 & 52.69032131 & 45.02534353 & 6.46493074 & 104.8915778 \\
\hline \multicolumn{8}{|c|}{ Level $4(n=10)$} \\
\hline $\mathrm{X}$ & 324.8860353 & $3.93327 \mathrm{E}-05$ & 0.002546525 & 0.00120202 & $1.66192 \mathrm{E}-05$ & 0.001584141 & 0.002626334 \\
\hline Sd. & 33.28306323 & 2.23574E-05 & 0.000153385 & 0.000403491 & $1.21621 \mathrm{E}-05$ & 0.000138094 & 0.002723886 \\
\hline Min. & 268.8440877 & $3.46042 \mathrm{E}-06$ & 0.002204143 & 0.000714104 & $5.6625 \mathrm{E}-06$ & 0.001359526 & 0.000205376 \\
\hline Max. & 375.0664526 & $6.93794 \mathrm{E}-05$ & 0.002697474 & 0.001698555 & $4.54555 \mathrm{E}-05$ & 0.00179782 & 0.007831575 \\
\hline $\mathrm{cv}$. & 10.24453489 & 56.84187465 & 6.023306707 & 33.56774047 & 73.18107968 & 8.717256685 & 103.7143698 \\
\hline \multicolumn{8}{|c|}{ Level 5 (n=9) } \\
\hline $\mathrm{X}$ & 337.6902622 & $3.50488 \mathrm{E}-05$ & 0.002226649 & 0.000866548 & $1.03717 \mathrm{E}-05$ & 0.001463152 & 0.00120908 \\
\hline Sd. & 29.98163218 & $5.48815 \mathrm{E}-05$ & 0.000356292 & 0.000410659 & $5.88089 \mathrm{E}-06$ & 0.000130357 & 0.001137393 \\
\hline Min. & 297.6513644 & 4.3615E-06 & 0.001702992 & 0.00034851 & $3.27496 \mathrm{E}-06$ & 0.001322742 & 2.43404E-05 \\
\hline Max. & 381.8572499 & 0.000167504 & 0.002760948 & 0.001481768 & $2.00511 \mathrm{E}-05$ & 0.001735812 & 0.002927758 \\
\hline cv. & 8.878441442 & 156.5857546 & 16.00125026 & 47.39019096 & 56.70150847 & 8.909318955 & 94.07100012 \\
\hline
\end{tabular}




\section{Conclusion}

Neolithic human and animal bone remains recovered from Tepecik-Çiftlik were examined by analyzing element concentrations and multivariate statistical elaborations. The studied elements normalized with calcium to eliminate the effects of diagenesis. This treatment helped us to understand individual dietary habits by comparing proposed parameters. The details of dietary habits through the levels of Neolithic Periods were investigated by multivariate analysis, excluding any post-mortem contribution. As a result, we observed a shift from a diet based on significant meat consumption to one based predominantly on vegetables, especially cereals, towards the end of the Neolithic Period. For future studies, this analysis will constitute a comparison base for stable isotopes analysis, and contribute to a better understanding Anatolian Neolithic dietary habits.

\section{Conflict of interest}

We declare that we have no conflict of interest.

\section{Acknowledgements}

The authors wish to thank the Tepecik-Çiftlik excavation director Assoc. Prof. Dr. Erhan Bıçakçı from İstanbul University, Prof. Dr. Yusuf Kağan Kadıŏlu from Ankara University, Earth Sciences Application and Research Center-YEBIM, Assist. Prof. Dr. Can Yumni Gündem from Batman University, Kiymet Deniz from Ankara University Earth Sciences Application and Research Center-YEBIM, and Gülşen Albuz Geren from Gazi University for laboratorial processes.

\section{References}

Ambrose, S. H., \& Krigbaum, J. (2003). Bone chemistry and bioarchaeology. Journal of Anthropological Archaeology, 22(3), 193-199. DOI: 10.1016/S0278-4165(03)00033-3

Balkan-Atlı, N. and Binder, D. (2012). Neolithic Obsidian Workshop at Kömürcü-Kaletepe (Central Anatolia) In: Özdoğan M, Başgelen N and Kuniholm P (Eds.), The Neolithic in Turkey (Vol.3), New excavations \& New Research, Central Turkey. İstanbul: Archaeology and Art Publications, pp.71-88.

Beck, L.A. (1985). Bivariate analysis of trace elements in bone, J. Hum. Evol. 14 493-502. https://doi.org/10.1016/S0047-2484(85)80028-2

Bıçakçı, E. (2001). Tepecik/Çiftlik Höyüğü (Niğde) 1şı̆̆ında Orta Anadolu Tarihöncesi kültürleri ile ilgili yeni bir değerlendirme. Tüba-Ar 4: 25-41.

Bıçakçı, E., Godon, M., Çakan, Y.G. (2012). Tepecik-Çiftlik. In: M. Özdoğan, N. Başgelen \& P. Kuniholm (Eds.) The Neolithic in Turkey (Vol 3), New excavations \& New Research, Central Turkey. İstanbul: Archaeology and Art Publications, pp.89-134.

Bıçakçı, E., Altınbilek, Algül, Ç., Balcı, S, Godon M. (2007). Tepecik-Çiftlik. In: M. Özdoğan \& N. Başgelen (Eds.), Türkiye'de Neolitik Dönem. İstanbul: Arkeoloji ve Sanat Yayınları, pp.237-253.

Binder D. (2002). Stone making sense: what obsidian could tell about the origins of the Central Anatolian Neolithic. In: Gerard, F. and Thissen, L. (Eds), The Neolithic of Central Anatolia, Internal developments and external relations during the 9th-6th millennia cal BC. İstanbul: Ege Yayınlar1, pp.79-90.

Buikstra, J.E. and Ubelaker, D.H. (1994). Standards for data collection from human skeletal remains. Arkansas Archeological Survey Research Series No. 44, Arkansas.

Busetto, M., Giordani, L., Brandone, A., Cattaneo, C., Mazzucchi, A. (2008). Dietary Investigation by Trace Element Content in Bones of Ancient Inhabitants of Northern Italy. Journal of Radioanalytical and Nuclear Chemistry, 275 (2): 355-363. doi:10.1007/s10967-0077070-x 
Büyükkarakaya, A.M., Erdal, Y.S., Özbek, M. (2009). Tepecik-Çiftlik İnsanlarının Antropolojik Açıdan Değerlendirilmesi. Arkeometri Sonuçları Toplantısı 24: 119-138.

Büyükkarakaya, A.M., Erdal, Y.S., Özbek, M. (2012). Tepecik-Çiftlik Höyük'te Bulunan Neolitik Dönem Kolektif Gömünün Paleoantropolojik Analizi. 34. International Symposium of Excavations, Surveys and Archaeometry, Çorum, 28th May-1st June.

Büyükkarakaya, A.M. and Erdal, Y.S. (2014a). Tepecik-Çiftlik Neolitik Topluluğunda Beslenme ve Diş Sağlığı. 36th International Symposium of Excavations, Surveys and Archaeometry, Gaziantep, 2nd-6th June 2014.

Büyükkarakaya, A.M. and Erdal, Y.S. (2014b). New Data on Mortuary Practices from the Early Pottery Neolithic Site of Tepecik-Çiftlik, Central Anatolia. 20th Annual Meeting of European Association of Archaeologists, İstanbul, 10th-14th September, pp.525.

Corti, C., Rampazzi, L., Ravedoni, C., Giussani, B. (2013). On the use of trace elements in ancient necropolis studies: Overview and ICP-MS application to the case study of Valdaro site, Italy. Microchemical Journal, 110: 614-623.

Çakan, Y.G. (2013). Tepecik-Çiftlik Son Neolitik Dönem Mimarisi. İstanbul (Unpublished MA thesis).

Fabig, A., Herrmann, B. (2002). Trace elements in buried human bones: intra-population variability of $\mathrm{Sr} / \mathrm{Ca}$ and $\mathrm{Ba} / \mathrm{Ca}$ ratios e diet or diagenesis? Naturwissenschaften, 89: 115-119.

Fornaciari, G., Trevisani, E.M., Ceccanti, B. (1984). Indagini Paleonutrizionali e Determinazione del Piombo Osseo Mediante Spettroscopia ad Assorbimento Atomica su Resti Scheletrici di Epoca Tardo Romana (IV sec d.C.) della Villa dei Gordiani (Roma). Archivio per L'Antropologia e L'Etnologia 114 - 149. (In Italian).

Elliott, T.A. and Grime, G.W. (1993). Examining the diagenetic alteration of human bone material from a range of archaeological burial sites using nuclear microscopy. Nuclear Instruments \& Methods in Physics Research B, 77 (1-4): 537-547.

González-Reimers, E., Velasco-Vázquez, J., Arnay-de-la-Rosa, M., Alberto-Barroso, V., Galindo-Martín, L., Santolaria-Fernández, F.B. (2003). Cadmium and lead in prehistoric inhabitants and domesticanimals from Gran Canaria. Sci Total Environ, 301: 97-103. DOI: 10.1016/S0048-9697(02)00299-1

Giorgi, F., Bartoli, F., Iacumin, P., Mallegni, F. (2005). Oligoelements and isotopic geochemistry: a multidisciplinary approach to the reconstruction of the paleodiet, Human Evolution, 20: 55-82. Doi:10.1007/BF02438898

Hedges, R.E.M. (2002). Bone diagenesis: an overview of processes. Archaeometry, 44: 31928. DOI: $10.1111 / 1475-4754.00064$

Janos, I., Szathmary, L., Nadas, E., Beni, A., Dinya, Z., Mathe, E. (2011). Evaluation of elemental status of ancient human bone samples from Northeastern Hungary dated to the 10th century AD by XRF. Nucl. Instrum. Methods Phys. Res. B, 269: 2593-2599. http://dx.doi.org/10.1016/j.nimb.2011.07.016.

Iscan, M.Y, Loth S. R, Wright R. K. (1984). Age estimation from the rib by phase analysis: White males, Journal of Forensic Science, 29; 1094-1104.

Iscan, M.Y., Loth, S. R., Wright R. K. (1985). Age estimation from the rib by phase analysis: White females, J. Forensic Sci., 30; 853-863.

Kyle, J.H. (1986). Effect of post-burial contamination on the concentrations of major and minor elements in human bones and teeth. The implications for palaeodietary research. Journal of Archaeological Science, 13:403-16.

Klepinger, L.L. (1984). Nutritional assessment from bone. Annual Review Anthropology, 13: 75-96.

Lambert, J.B., Szpunar, C.B., Buikstra, J.E. (1979). Chemical analysis of excavated human bone from Middle and Late Woodland sites. Archaeometry, 21: 115-129. 
Lovejoy, C.O., Meindl, R.S., Pryzbeck, T.R., Meinsforth, R.P. (1985). Chronological metamorphosis of the auricular surface of the ilium: a new method for the determination of adult skeletal age at death. American Journal of Physical Anthropology, 68: 15-28. DOI: 10.1002/ajpa.1330680103

Martínez-García, M.J., Moreno, J.M., Moreno-Clavel, J., Vergara, N., García-Sánchez, A., Guillamón, A., Portí, M., Moreno-Grau, S. (2005) Heavy metals in human bones in different historical epochs. Sci Total Environ 348:51-72.

DOI: $10.1016 /$ j.scitotenv.2004.12.075

Mays, S. (2003). Bone strontium: calcium ratios and duration of breastfeeding in mediaeval skeletal population. Journal of Archaeological Science, 30: 731-741. doi:10.1016/S03054403(02)00247-9

Meindl, R.S., Lovejoy, C.O. (1985). Ectocranial Suture Closure: a revised method for the determination of skeletal age at the death based on the lateral-anteior sutures. American Journal of Physical Anthropology, 68: 57-66. DOI: 10.1002/ajpa.1330680106

Nelson, D.A., Sauer, N.J. (1984). An evaluation of postdepositional changes in the trace element content of human bone. American Antiquity, 49 (1): 141-147.

Nicholson, R.A. (1996). Bone degradation, burial medium and species representation: debunking the myths, an experiment-based approach. Journal of Archaeological Science, 23: 513-33.

Özdemir, K. (2008). İkiztepe Tunç Çağı Topluluğunda Element Analizleriyle Beslenme Yapısının Belirlenmesi, Yayınlanmamış Doktora Tezi, Hacettepe Üniversitesi, Ankara. (In Turkish with English abstract).

Özdemir, K., Erdal, Y.S., Demirci, Ş. (2010). Arsenic accumulation on the bones in the Early Bronze Age İkiztepe Population, Turkey. Journal of Archaeological Science, 37 (5); 10331041. https://doi.org/10.1016/j.jas.2009.12.004

Price, T.D., Blitz, J., Burton, J., Ezzo, J.A., 1992. Diagenesis in prehistoric bone: problems and solutions. J. Archaeol. Sci. 19, 513-529.

Radosevich, S.C. (1993). The six deadly sins of trace element analysis: a case of wishful thinking in science. In: Sandford MK, editor. Investigations of ancient human tissue. Chemical analyses in anthropology. Gordon and Breach Science Publishers; p. 269-332.

Salmon, M.E. (1970). An X-Ray Fluorescence Method for Micro-Samples, IIC-American Group Technical Papers from 1968 through 1970; IIC-American Group: New York, 31-46.

Sandford, M.K. (1992). A reconsideration of trace element analysis in prehistoric bone. In: Saunders R, Katzenberg A, editors. Skeletal biology of past peoples: research methods. New York: Wiley-Liss; 79-103.

Sevdin, E.E. (2017). Farkli Arkeolojik Kemik Türlerinde Element Birikiminin Değerlendirilmesi: Tepecik-Çiftlik Örneği (Determination of Elemental Accumulation on the Different Archaeological Bone Types: Tepecik-Çiftlik Example). Yayınlanmamış Yüksek Lisans Tezi (Unpublished Master Thesis), Hacettepe Üniversitesi, Ankara.

Shafer, M.M., Siker, M., Overdier, J.T., Ramsl, P.C., Teschler-Nicola, M., Farrell, P.M. (2008). Enhanced methods for assessment of the trace element composition of Iron Age bone. Science of Total Environment, 401: 144-161. https://doi.org/10.1016/j.scitotenv.2008.02.063

Szostek, K., Glab, H., Lorkiewicz, W., Grygiel, R., Bogucki, P. (2005). The diet and social paleostratigraphy of Neolithic agricultural population of the Lengyel culture from Oslonki (Poland). Przeglad Antropologiczny - Anthropological Review, 68: 29 - 41.

Şevketoğlu. M. (2006). Cypro-Anatolian relations in the 9th millenium B.C.: Akanthou / Tatlisu Rescue Excavation. Anatolia, 30: 119-136.

Şevketoğlu, M. (2008). Early settlements and precurement of raw materials-new evidence based on research at Akanthou-Arkosykos (Tatlısu-Çiftlikdüzü), Northern Cyprus. TÜBA-AR $X I, 63-72$. 
Ubelaker, D.H. (1989). Human skeletal remains (2nd ed.). Smithsonian Institution, Washington.

Uzun, K. (2016). Klozemenai Dalgalı Çizgili Seramiği: MÖ 650-550. Süleyman Demirel Üniversitesi, Fen-Edebiyat Fakültesi, Sosyal Bilimler Dergisi, 38:97-124.

Zapata, J., Pérez-Sirvent, C., Martínez-Sánchez, M.J., Tovar, P. (2006). Diagenesis, not biogenesis: Two late Roman skeletal examples. Science of Total Environment, 369: 357-368. DOI: $10.1016 /$ j.scitotenv.2006.05.021 